\title{
A Multicultural Education Praxis: Integrating Past and Present, Living Theories, and Practice
}

\author{
Peggy Shannon-Baker \\ Georgia Southern University
}

U.S. A.

\begin{abstract}
In our current climate of heightened conservatism and criticism, multicultural education is as important as ever. This article argues for the need to reframe multicultural education as a praxis based on its social justiceoriented principles, values, and practices. Using practitioner action research, I examine my implementation of such a praxis in a college course. I discuss critical reflections on demonstrating the interconnections between current and historical social movements, theory and lived experiences, and the students' and my learning. I conclude by arguing that reframing multicultural education as a praxis could encourage more coalitions within and beyond schools.
\end{abstract}

KEYWORDS: praxis, critical, multicultural education course, culturally relevant teaching, practitioner research

\author{
Contexts \\ Practitioner Action Research Methods \\ Connecting Present to the Past \\ Theorizing Lives / Living Theories through Testimonial Reading \\ Multicultural Education as Praxis \\ Critical Reflections \\ Conclusions \\ Notes \\ References \\ Author Contact
}

Multicultural education identifies a set of principles, values, and practices that can be embodied in all professional arenas. I argue that practitionersteachers, researchers, activists, and community leaders-can frame their work based on those values, i.e., through a multicultural education praxis. I demonstrate this by analyzing how I enacted such a praxis while teaching an interdisciplinary college course. I begin by first mapping the various disciplinary, personal, and institutional contexts that inform my multicultural education praxis and this writing. Next, I discuss the course design and implementation of practitioner action research methods. I organize my discussion in three categories: connecting today's social movements to the past, demonstrating how lived experiences and multicultural education theories can be integrated using testimonial reading, and 
identifying what it means to demonstrate multicultural education in practice. Then, I share my critical reflections on the course, including what subverted this praxis. I conclude with a discussion of the implications of reframing multicultural education as a praxis.

\section{Contexts}

Multicultural education represents a set of principles, values, and practices that are directly linked to social justice (Au, 2009; Gorski, 2009; Nieto \& Bode, 2012), where social justice refers not only to a critical interrogation of power, privilege, and discrimination, but also to acts that intentionally disrupt or respond to systemic oppression (Salazar \& Rios, 2016). Within the United States, multicultural education was born out of the Civil Rights Movement and the development of ethnic studies and multiethnic education (Banks, 2013; Sleeter, 1996). It is based on a central belief that "all students...should have an equal opportunity to learn" (Banks, 2010, p. 3). Thus, multicultural education seeks to ensure such opportunities for all students, from micro-level classroom practices to macro-level national and international education policy.

In our current international context of increased conservatism, defunding of public schools, and neocolonialism (cf. Gorski, 2012; Livingston \& Flores, 2017), there is concern about the future of multicultural education. Both the understandings and implementations of multicultural education vary throughout the world (e.g., Baratz, Reingold, \& Abuhatzira, 2011). For some, this variability hinders its implementation in more schools (Muchenje \& Heeralal, 2014). There is some question about the meaning of "multicultural education," especially within particular localities (Hirasawa, 2009; Jackson, 2013). This context that is critical of multicultural education has prompted the use of other frames such as interculturalism (Jackson, 2013), as well as inspired the development of typologies of multicultural education (e.g., Jenks, Lee, \& Kanpol, 2001). Others have stated that their own local contexts, like that of Hong Kong, are in a "post-multicultural" period (Jackson, 2013, p. 100).

In response to such revisionings and criticism, I argue that we need to envision a multicultural education praxis that addresses "global issues of equity and power" (Gutiérrez, 2000, p. 214) and demonstrates how theories can be integrated with practice (Cohen et al., 2013; Herrera, Holmes, \& Kavimandan, 2012). A multicultural education praxis in the classroom empowers youth, builds a community among teachers and learners loosely defined, shares power, and critically analyzes both institutional structures and personal practices that maintain oppressive systems. It encourages us to interrogate: how knowledge is constructed and communicated; how we interact with and support others, especially across difference; and how diversity is represented or erased (Banks, 2010; Herrera et al., 2012). This praxis includes the promotion of cognitive justice, or the acceptance of various forms of knowledge, through the integration of indigenous ways of knowing (Muchenje, 2017). 
Within teacher preparation programs in the United States, multicultural education - as a separate class or guiding framework for the whole program-is used as a means to train future teachers to be more culturally relevant (LadsonBillings, 2011; Lopez, 2011; Milner, 2011). It also addresses pre-service teachers' "fear of diversity and resistance to dealing with race and racism" (Gay \& Howard, 2000 , p. 1). Such courses are seen as a response to the "demographic divide" in the United States between preservice teachers, most of whom are White middle class women, and the increase in racial, ethnic, and socioeconomic diversity in public schools (Gay \& Howard, 2000; Howard, 2010). Programs that not only teach about multicultural education but also embody its values model the approach that students will then use in the future. Thus, teacher preparation programs are positioned to make changes in schools through the training of future teachers (Paul-Binyamin \& Reingold, 2014).

There are, however, strong critiques that argue that these courses and programs are not doing enough (e.g., Convertino, 2016; Gorski, 2009; PaulBinyamin \& Reingold, 2014). Muchenje and Heeralal (2014) argue that the numerous ways multicultural education has been defined have led to inconsistent conceptualizations of it and thereby to varying levels of implementation in schools. Other critiques point to how such courses rely on deficit thinking, promote dichotomous conceptualizations of identity, disregard intersectionality, and "obscure" the connections between theory and lived experiences (Cohen et al., 2013, p. 264; Gorski, 2009; Herrera et al., 2012; hooks, 1994; Valencia, 2010). Additionally, both the research on multicultural teacher education and the design of such courses share a disturbing trend: both tend to focus almost exclusively on White pre-service teachers (cf. Gorski, 2009), sometimes even silencing students of color (Sheets \& Chew, 2002; Smith, 2014). These critiques reveal that teachers (and other practitioners) need to continue to engage in critical reflection about our work and how it embodies (or does not embody) the core values about which we teach.

These critiques about theory and action, dichotomies, and deficit thinking have greatly impacted my own views about teaching and learning. My pedagogy is based on my positionality as a queer White anti-racist feminist and a firstgeneration college graduate. Growing up, I lived in a variety of places throughout the United States, including a city and suburban towns in the Midwest and rural towns in New England. I am also an adoptee and have been homeless. I use these identities as insider and outsider lenses that are simultaneously linked to power and privilege (Gutiérrez, 2000; Kedley, 2015; Smith, 2014). I position myself in the classroom in a way that demonstrates that I am as much of a learner as the students are teachers; it isn't "my class" or "my students," but our class. This disrupts notions of power and privilege between teacher and student (M. Britt, personal communication, July 30, 2017). In this way, we co-create shared learning spaces (Shannon-Baker \& Wagner, in press) while engaging in critical reflections about biases, privilege, and power (Howard, 2003). ${ }^{1}$ Whenever possible, I also design field work that engages in culturally relevant relationships with the local community (Shannon-Baker \& Talbot, 2016). ${ }^{2}$ 
I designed the course ${ }^{3}$ discussed here for an education program situated in an elite all-women's college. Although the course was designed primarily for future teachers, it was open to all majors as well as students from a neighboring institution. It was a semester-long course that met twice per week. The major assignments included 10 weekly journals, observation notes from 16 hours of a field experience, a research project called the "Showcase Project," and a final Reflective Portfolio. The course had 26 students, one of whom withdrew due to illness. The students varied in terms of age, year in their program, and major (e.g., education, psychology, sociology). Fifteen students self-identified as students of color. Several students self-identified as working class, first-generation college students, and/or LGBTQ.

\section{Practitioner Action Research Methods}

This work draws from practitioner action research that positions the work of teachers as worthy research endeavors that can then be used to improve practice and community embodiments of emancipatory ideals (Cochran-Smith \& Lytle, 2009; Howard, 2003; Hubbard \& Powers, 2003). Practitioner inquiry in education settings takes a critical view of schooling; focuses on the construction of knowledge; asks critical questions of the teacher's practice, values, and intentions; and integrates theory and practice (Convertino, 2016; Kemmis, 2006).

My practitioner inquiry utilized two types of reflection: reflection-in-action, in which the practitioner reflects on their work while doing it, and reflection-on-action, or reflection done retrospectively (Schön, 1987). Whereas the former inspires improvisation to address immediate issues in the classroom, the latter builds knowledge based on situating reflections in their social context. Both types of reflections are necessary for a holistic and mindful reflective practice (Leitch \& Day, 2000). The data sources included my weekly teacher journals, lesson plans, lecture materials, course design notes, syllabus, schedule, readings, and students' work. ${ }^{4}$ As a practitioner-focused study, I produced/created most of this data; data was not systemically collected from students, but I did share this manuscript with several students while writing. ${ }^{5}$

After the course was completed, I compiled the data and conducted several iterative close readings. I used the following questions to guide my analysis:

- When did my practice embody a multicultural education praxis? What specific activities, readings, topics, and discussion formats did this entail?

- When did my practice not embody a multicultural education praxis? What broke down and why?

- What changes could be made in the future and why? 
- What do the findings reveal about schooling and about multicultural education? How do the findings consider broader questions about education for social justice?

I wrote regular memos with each round of the analysis and while writing the findings. These memos also prompted a re-reading of the data. In the subsequent sections, I organize my findings based on how my multicultural education praxis relates to social movements today, theoretical ideas and concepts, and enactment of multicultural education today. In each section, I detail the relevant activities and readings, my reflections on the intended design and implementation, and the course assessments. Table 1 provides a comprehensive list of these strategies.

Table 1. List of Potential Strategies to Use in the Classroom that Embody a Multicultural Education Praxis

\begin{tabular}{|c|c|}
\hline Topic & Strategies for the Classroom \\
\hline $\begin{array}{l}\text { Defining and } \\
\text { framing multicultural } \\
\text { education within its } \\
\text { historical and } \\
\text { contemporary } \\
\text { contexts }\end{array}$ & $\begin{array}{l}\text { - Investigate the history of the field, idea, and concept of } \\
\text { multicultural education } \\
\text { - Discuss current social justice movements } \\
\text { - Analyze "safe" versions of history versus more critical } \\
\text { versions; Design more critical lessons } \\
\text { - Utilize current social media and technology as a medium } \\
\text { for assignments and discussions }\end{array}$ \\
\hline $\begin{array}{l}\text { Connecting theories } \\
\text { to lived experiences } \\
\text { and vice versa }\end{array}$ & $\begin{array}{l}\text { - Read and discuss testimonios with critical empathy and } \\
\text { personal responsibility } \\
\text { - Start from local/regional issue } \\
\text { - Utilize multimedia resources, e.g., films, interactive } \\
\text { - Presentations, and comics } \\
\text { readings } \\
\text { - Encourage students to share by sharing your own stories } \\
\text { - Enact an anti-voluntourist approach in multicultural field } \\
\text { experiences }\end{array}$ \\
\hline $\begin{array}{l}\text { Teaching and } \\
\text { modeling a } \\
\text { multicultural } \\
\text { education praxis }\end{array}$ & $\begin{array}{l}\text { - Share teaching practices, decisions, and rationales with } \\
\text { students whenever possible } \\
\text { - Assign projects that engage students' autonomy } \\
\text { - Design assignment rubrics as a class } \\
\text { - Facilitate peer-to-peer feedback with intentional } \\
\text { pairing/grouping of students; Provide a loose structure to } \\
\text { guide the feedback } \\
\text { - Own mistakes and practices that subverted the praxis } \\
\text { publically to the class } \\
\text { - Engage in concurrent and retrospective critical reflections; } \\
\text { Share whenever possible }\end{array}$ \\
\hline
\end{tabular}




\section{Connecting Present to the Past}

Sleeter (1996) argued that multicultural education coursework was "severed from any social movement" (p. 239). This issue still remains today. I have found that organizing course topics by identity groups (e.g., race, socioeconomic class)a structure commonly used in diversity courses in the United States (e.g. Gorski, 2009 and Appendix E in Smith, 2014) - discourages intersectional understandings of both identity and our interaction with oppressive systems. With this in mind, I began the course with current social movements, i.e., Black Lives Matter, Native Lives Matter, and the undocumented student movement, in order to make the case for why multicultural education remains vital.

Our discussions about the Black Lives Matter movement were timed to teach in solidarity with a local group that organized a teach-in about the movement in public schools (Caucus for Working Educators, 2017). We learned that these movements shared similar historical underpinnings with the development of multicultural education (Garza, 2014; Guiding Principles | Black Lives Matter, n.d.; Wallace, 2016). Some students stated that talking about the Black Lives Matter movement in particular was validating and created space in the classroom to talk about the persistent violence against people of color. Many students stated that they were unfamiliar with indigenous peoples' movements. They were also surprised to learn about the convergences and divergences between these movements and Black Lives Matter (e.g., Simpson, 2014). By investigating current social movements within their historical contexts, we were able not only to address the persistence of racist violence but also call attention to our own collective miseducation about historical movements and people.

It was based in this historical understanding that I led an in-class activity on the additive approach to multicultural education (Banks, 2010). I prefaced the activity by discussing how some manifestations of multicultural education include a focus on "heroes and holidays," also referred to as "ethnic tidbits" (Nieto, 2003). I argued that although learning about historical figures of color is important, these manifestations often rely on "safe" versions of their stories, e.g., that Rosa Parks was just tired one day instead of having been trained in nonviolence with an organized group of activists. In the activity, the students identified "safe" lessons for a particular age level, critiqued the implications of teaching that narrative, and identified more critical sources for the relevant age group. This information was then shared on our class website. This activity established that we would be critical readers of examples of multicultural education in practice. This activity also demonstrated that as a community of practice, we could together identify critical practices, resources, and activities in which to engage.

A key feature of my approach of connecting the past and present was the use of multi-modal and social media-based journals. Although the first four journals required a traditional written format, the subsequent four were "creative journals."

For these journals, I asked the students to draw, for example, what a reciprocal 
relationship between a community and school looked like. Another prompt asked the students to share their learning about multicultural education through Twitter. Given the short format, students had to summarize their thoughts concisely. All tweets included our class hashtag, \#BMCMulticulturalEd. Each tweet also needed to include an interactive component, such as tagging a guest speaker using their Twitter handle, or attaching an image. These tweets helped the students connect with the authors we read and encouraged further conversation outside of our class. For one student, linking to outside sources presented a welcome "challenge" to explore her thinking further (M. Britt, personal communication, July 30, 2017). These journals were also intended to encourage students to see how social media can be used in a multicultural education praxis.

\section{Theorizing Lives / Living Theories through Testimonial Reading}

I led our investigation of theories related to multicultural education through the use of narratives about lived experiences (e.g., Shannon-Baker \& Wagner, in press). This approach evoked a testimonial reading that not only involved empathy for the person's story, but also required us to interrogate our own responsibility in that person's experiences (Boler, 1997). The important distinction here is that we did not put ourselves in the shoes of the Other, which would provoke the need to protect ourselves rather than understand another's experiences (Boler, 1997). Instead, we had to accept personal complicity and responsibility in order to turn our knowledge and empathy into action.

One example of how we used testimonial reading was our lesson about gentrification, or the process of displacing communities of people of color and working-class people. This lesson was embedded in a unit about the interconnections between community, education, and schooling. I partnered readings about gentrification (e.g., Kozol, 2005) with a historically situated ethnographic video called "Good White People" about the effects of gentrification in Cincinnati, Ohio (Welling-Cann \& Stoll, 2016). First, we listed phrases for gentrification that the students had heard before: redevelopment, cleaning up the neighborhood, revitalization, and urban renewal. Then, I asked the students to document their reactions while we watched the film. This was followed by silent writing and small group discussions. One student remarked how Reginald, a local father and businessman in the film, was so calm about being displaced from his community. Other students and I were struck by the juxtaposition between Reginald packing his family's belongings and a group of White people laughing and waving from a bar in the film's closing scene. Asking why we had such emotional reactions revealed our own historical connections to being displaced by gentrification, as well as how we contributed to its forces by celebrating such "redevelopments" locally. The testimonial reading of gentrification made this intangible and seemingly distant process real, personal, and emotional.

We also drew from our own lives to understand theories and concepts related to multicultural education. To do this, I incorporated students' experiences 
and background knowledge into our class activities and assignments. In one example, I asked the students to write about something they achieved through hard work. We then analyzed these narratives in relation to the American Dream, or how people can succeed if they put in hard work, and neoliberalism, or the systemic emphasis on objectivity, meritocracy, and individualism (Augoustinos, Tuffin, \& Every, 2005; Tuck, 2013). We talked about how these discourses centered on the individual, luck, and meritocracy, and thereby erased structural access to privilege, the importance of family, and the impact of others' help. The students then analyzed their own narratives and added in the people and/or structures that helped them. The following week, I too shared my experiences of attaining a doctoral degree and the advantages I received on individual and institutional levels. The goal was twofold: disrupt the individualized rhetoric of success in the United States and practice writing our personal stories in a way that recognized both individual and structural privileges. Thus, we extended the testimonial reading approach by asking how we are implicated in systems of privilege and access.

The major assessment for the course that linked theory and lived experiences was the field experience. This assessment entailed eight weeks in a "multicultural" setting. These settings included primary level classrooms, multilingual schools, and after-school programs; and community programs and institutions. Although I did not assign the placements ${ }^{6}$, my goal for this field experience was to have a space from which to draw connections to our class content. For example, we connected these field experiences to the notion of voluntourism. Voluntourism reflects the current trend of Westerners to combine vacation trips with local volunteering that often does more harm than good (Kushner, 2016). We critiqued the underlying assumption of such work, i.e., volunteers "chose hardship and survived it" (Zakaria, 2014), whereas others live these "hardships" not by "choice." Some students shared that their peers had participated in such programs to have an "experience" to write about in their college essays (e.g., Bruni, 2016). I assigned a creative journal in which the students played the role of a field placement coordinator. They then created a document that communicated an anti-voluntourist approach to the field experience. The students were able to articulate not only the harm that such an approach has, but also specific strategies for how to combat it, such as remaining humble, interrogating one's privileged stances, and checking one's intentions and assumptions. By having us think about how the general structure of multicultural field placements resembles voluntourism, we could interrogate our own responsibility in this system. This led students to reflect critically on their interactions while in the field.

\section{Multicultural Education as Praxis}

As hooks (1994) once said, "Education as the practice of freedom is not just about liberatory knowledge, it's about liberatory practice in the classroom" (p. 147, 
emphasis added). I interpret this "practice" to relate to both the teacher and students. In this section, I detail examples of a multicultural education praxis demonstrated by the students in their "Showcase Projects" and by myself in the form of culturally relevant pedagogy.

A major assessment in the class was a multi-modal, research-oriented assignment called the "Showcase Project." Its goal was to evaluate a current educational issue and frame it within multicultural education. In designing their project, the students had to consider the following: who is the audience, what is the message, and what is the best way to communicate that message to that audience? The students worked incrementally on the project throughout the second half of the semester, including individual meetings with me, in-class working time, peer-to-peer workshops, and a final two-day "Live Event" where the students shared their projects with the class. Many of the topics students selected represented a "critical institutional analysis" (Gorski, 2009, p. 315), such as examining how school uniform policies regulate youths' bodies using racial and gendered standards of the body. Other projects included a webpage on how to talk to middle school children about race, and a play that juxtaposed the impact of monolingual and bilingual education on multilingual students' development.

The students chose their own medium for the project, so long as it was not a traditional research paper. Multi-modal projects-i.e., visual, auditory, and participatory projects that do not rely heavily on a traditional essay-access other forms of intelligence (Gardner, 1983/2011). I designed this project to be multimodal because I recognized that the traditional research paper was acting as a barrier (Sleeter, 1996) to envisioning how multicultural education could be embodied in everyday practice. By creating a video or writing a children's book, the students had to understand not only their content and argument, but also their intended audience and the best mechanism through which to communicate.

The peer-to-peer workshop time was crucial to the development of their projects. These workshops provided space for feedback and idea sharing. When I asked some students how they felt about such workshops in the past, I learned that they found them largely unhelpful because of a lack of structure. In response, I provided a loose set of structured questions for the workshop sessions. I also intentionally paired the students. The first pair shared a similar topic or idea to get content-based feedback. The second pairing was based on their medium choice to get feedback in that realm. The peer-to-peer and small-group interactions provided support for developing students' self-efficacy and skills in multicultural education praxis (cf. Herrera et al., 2012).

We also co-created the rubric for the project as a class. Although this required about three hours of in-class time to complete, creating a rubric as a class was beneficial for many reasons. It demonstrated how students can interpret wording on a rubric or assignment differently from the teacher's original intention. We had to navigate how to come to consensus about issues such as what constitutes a "strong" or "academic" reference. As the instructor, I also had to redirect questions like "Well, what do you want us to do?" back to the class to position the students as authority figures. We also had to overcome the challenge 
of writing a rubric that could be used to assess anything from a play to a blog to a collection of poems. Ultimately, by creating the rubric the students practiced a multicultural education approach that supported community-building, agency, authority, and creativity.

As the instructor, I demonstrated a multicultural education praxis through embodying a culturally relevant pedagogy: the centering of students' knowledge and experiences, building deep relationships, and incorporating content and activities that directly connect with students (Howard, 2003; Ladson-Billings, 2011; Lopez, 2011; Milner, 2011). For teacher educators, culturally relevant pedagogy is not only a topic to teach about but also one that must be modeled. "Yet, to fully understand what such theory means for daily instruction, teachers need to actually experience this type of instruction" (Herrera et al., 2012, p. 3).

I believe that culturally relevant pedagogy is also about recognizing my own faults and mistakes in the class and discussing those with the class as a way to disrupt teacher-student power dynamics. During our week about theories of power and privilege, we discussed microaggressions, the daily comments, or acts that reveal stereotypical and discriminatory beliefs based on race, gender, class, and other identities (Solórzano, 1998; Sue et al., 2007). One White student shared in class that they always called out microaggressions addressed to them. Seeing this as a teachable moment, I intervened, saying that some people face so many microaggressions in a day that they no longer want to call out and educate the person every time. I shared a video that draws an analogy between microaggressions and mosquito bites to show how so many "bites" over time have an impact (Fusion Comedy, 2016). In that moment, I felt it was my responsibility as a White person and as the instructor to complicate what the student said. At other times in the semester, the students and I called others out when they misgendered an author or assigned them a male or female pronoun based on assuming their gender from their first names. I shared with the students how I personally try not to gender authors without first researching how they refer to themselves, such as in author bios.

However, this work also entails calling out my own microaggressions. As part of an initiation activity that a group of the students designed for me as a new professor, I had to give compliments to a student whenever they ate a snack during class. At the beginning of class, everyone had snacks, so I tried to quickly go around the room and give compliments. Despite wanting to give academically oriented compliments during this activity, many of the compliments I gave were on visible aspects, such as handwriting or something they wore. It was in my critical reflections that I recognized that many of my compliments, the pauses I took (as opposed to my readiness to give a compliment to a male student), or even the hesitation about not giving a compliment to a student of color could all be considered microaggressions. Recognizing this as another teachable moment, I called myself out the next day in class. In doing so, I revealed my own vulnerabilities, enactments of privilege, and internalization of discriminatory discourses. I shared these reflections with the students as an embodiment of my own multicultural education praxis. 


\section{Critical Reflections}

According to Howard (2003), teachers' critical reflections require an examination of "how their positionality influences their students" and "should include an examination of how race, culture, and social class shape" both the students' and teacher's thinking (p. 197). This includes reflecting on how one's practices are influenced by and help to maintain dominant discourses including racism, sexism, and heteronormativity (Shannon-Baker \& Wagner, in press). Thus, it is important for me to ask tough questions about my own pedagogy and practices in this class.

There were moments in the class where the dissonance (Kasun, 2015) I felt with students indicated something deeper going on. For example, when re-reading my notes from my meetings with students and my weekly journals, I recognized that several students expressed confusion about the topic of "decolonizing" education. One reading argued that incorporating indigenous knowledge in science classrooms was a form of "decolonizing" the classroom or recognizing how schools in the United States teach only Western ways of knowing (Chinn, 2007). However, another argued that the process of decolonization is much more complicated and that such a "metaphorization of decolonization" only serves to ease the guilt of White people (Tuck \& Yang, 2012, p. 1). Initially, I thought that students seemed confused about this topic because I did not appropriately nor incrementally build their knowledge in it. Although this may be true, upon more critical reflection, I realized that the students' confusion actually reflected my own limited knowledge about decolonization. As Palmer (1998) once said, "The entanglements I experience in the classroom are often no more or less than the convolutions of my inner life" (p. 2). Despite seeing the importance of incorporating indigenous perspectives, I myself was not even fully prepared for such conversations. This revealed to me areas that I needed to further my own learning.

My conversations with a student about her Showcase Project prompted further critical reflection about my pedagogy and practices. In this case, the student's project was on the emotional work of multicultural education (Britt, 2017). We talked about respectability politics, or how marginalized groups have to conform to mainstream values and practices, and the perception that being "professional" in higher education required an erasure of personal experiences and emotions. She identified the importance of bringing in Audre Lorde's (1984/2007) work and how it blends art, poetry, emotions, and depth of meaning. The student's final product was about holding emotional space as a "Black femme" in an "elite setting" that blended poetry and academic writing (Britt, 2017). Her embrace of how difficult it was initially to let the work/emotions flow reminded me of my own experiences when I felt compelled to swallow emotions in educational settings. But her work was also rooted in the intersectionality of race, gender, and emotions. In her work, I recognized that apprehension was its own form of erasure and of internalized racism and sexism; wasn't the same then true of not holding space 
and recognizing emotions in the (multicultural education) classroom? I had left unasked questions about whose emotions and emotional narratives were valid in the classroom and only allowed those that served as a conduit for our learning. As Lorde (1984/2007) says, "The quality of light by which we scrutinize our lives has direct bearing upon the product which we live, and upon the changes we hope to bring about through those lives" (p. 36). Thus, we need to honor the emotional work of multicultural education that requires emotional reflective practice (Zeichner \& Gore, 1995) about our own responses as well as asking whose and what emotions are used for learning.

A third set of conversations with students that prompted critical reflection was about why I had been hired to teach the multicultural education course. This was a topic that came up in two individual meetings I had, as well as in one class discussion. Different iterations of the conversation directly or indirectly asked why I, as a White woman, was hired instead of a person of color. Each time, I spoke about my teaching background and shared my experiences growing up poor or developing my racial consciousness. However, it was in recognizing that this topic came up several times that I realized it revealed an important concern the students had about the politics of hiring practices in higher education. These conversations indicated that these students wanted to see more professors of color who looked like them. I recognized that I had failed to provide space to interrogate how institutional structures and individual actions intersect to provide/deny access to teaching opportunities, what experiences are valid, and who should be teaching such classes. This discussion represents critical issues for multicultural education coursework-i.e., addressing the challenges of teaching multicultural education (Gorski, 2012), which must also include asking who is not teaching it and why. Future research in this area should systemically investigate who is teaching multicultural education courses and what training is needed to do so (Gorski, Davis, \& Reiter, 2012; Stenhouse, 2012).

\section{Conclusions}

In this article, I detailed the design and implementation of a multicultural education praxis in an interdisciplinary college course. I elaborated on the importance of connecting current issues to their historical precedents. I discussed the implications of using testimonial reading to develop an understanding about theories and concepts based in lived realities. I also critically reflected on several moments when the class and my practice did not embody such a praxis and analyzed how and why it broke down. I had designed the course to respond to the critical limitations scholars have identified in other social justice and multicultural oriented coursework (Cohen et al., 2013; Gorski, 2009; Herrera et al., 2012). Among these issues are the importance of teaching not just about the ideas or theories related to multicultural education but also about their historical development and global interpretations (Boler, 1997; Gutiérrez, 2000). This discussion also responds to the call for more published examples of implementing 
culturally relevant pedagogy in heterogeneous classrooms (Gorski, 2009; Herrera et al., 2012).

This article also calls attention to some problematic practices in multicultural education coursework. These include organizing course topics by identity groups, relying heavily on writing-based assignments, not providing students with space to enact their agency, instructors asking only the students but not themselves to take on the risks of self-reflection, and requiring field experiences that reproduce colonialist relationships between higher education institutions and local communities. I myself have engaged in these practices, as both a student and as a teacher. By highlighting such practices, I aim to problematize these taken-forgranted dimensions and practices of multicultural education (Kemmis, 2006).

Finally, I also address the challenge of articulating what a multicultural education praxis "means for everyday practice" (Jackson, 2013, p. 101). I argue that multicultural education as a praxis honors the past, is theoretical and theorybuilding, and calls out practices/policies that are falling short in our aims for social justice. Reframing multicultural education as a praxis harkens back to Sleeter's (1996) argument that conceptualizing it as a movement can create a shift in power relations, dominant ideology, and the allocation of resources. As a praxis, the values of community partnership, equity, and social justice can be sought in realms inclusive of and beyond schooling. This repositioning can also promote coalition building with others working for social justice. The work of multicultural education is similar to that of social justice activism; both require constant critical reflection in order to adapt and make positive change for the future (M. Britt, personal communication, July 30,2017$)$. We need such coalitions in the work ahead.

\section{Notes}

1. Because of how I position myself in the classroom as both teacher and learner, I use first person plural pronouns (we, our) when writing about discussions or class activities in which I also participated. "The students" were not the only ones who wrote, reflected on, or discussed the content; "we" did this together whenever possible.

2. In the case of this class, students' placements in the field were coordinated by a staff person in the department. These placements were based on the students' time availability, their preferences for a particular type of placement (e.g., school or community program), and the availability of mentors in the field.

3. Although I had the privilege and opportunity to design this entire course (including the syllabus, readings, and assessments), I recognize that many instructors throughout the world are given pre-designed courses by their institutions. I have discussed elsewhere (Shannon-Baker \& Wagner, in press) how I have taught such pre-designed courses. Generally, if there is flexibility in how one teaches the course day-to-day or if additional materials can be brought in, this is where instructors can engage in critical dialogue about the material. It 
is my aim that the discussion of my classroom practices and how we addressed common topics or activities in multicultural education (e.g., field experiences) can help readers identify what adjustments can be made to fit their local contexts.

4. Although the analysis presented here was based primarily on my own data and experiences, any student work shared is done so with their permission received after the course was completed.

5. I would like to acknowledge and thank Maria Britt and Seanna Viechweg, who were students in this class, Sarah Rutherford, and the anonymous reviewers, all of whom provided feedback on earlier drafts of this manuscript.

6. See Note 2.

\section{References}

Au, W. (Ed.). (2009). Rethinking multicultural education: Teaching for racial and cultural justice. Milwaukee, WI: Rethinking Schools.

Augoustinos, M., Tuffin, K., \& Every, D. (2005). New racism, meritocracy and individualism: Constraining affirmative action in education. Discourse \& Society, 16(3), 315-340.

Banks, J. A. (2010). Multicultural education: Characteristics and goals. In J. A. Banks \& C. A. Banks (Eds.), Multicultural education: Issues and perspectives ( $7^{\text {th }}$ ed., pp. 3-30). Hoboken, NJ: Wiley.

Banks, J. A. (2013). The construction and historical development of multicultural education, 1962-2012. Theory into Practice, 52, 73-82.

Baratz, L., Reingold, R., \& Abuhatzira, H. (2011). Bi-lingual newspaper as an expression of a fake multicultural educational policy in Israel. International Education Studies, 4(4), 160-169.

Boler, M. (1997). The risks of empathy: Interrogating multiculturalism's gaze. Cultural Studies, 11(2), 253-273.

Britt, M. (2017, April 20). Emotion reimagined (in multicultural education) [Web log]. Retrieved from http://mbritt.blogs.brynmawr.edu/2017/04/20/emotionreimagined-in-multicultural-education/\#more-73.

Bruni, F. (2016, August 13). To get to Harvard, go to Haiti? [Op Ed]. The New York Times. Retrieved from https://www.nytimes.com/2016/08/14/opinion/ sunday/to-get-to-harvard-go-to-haiti.html

Caucus for Working Educators. (2017, January 15). Why the Black Lives Matter movement is vital for us all. Retrieved from http://www.workingeducators.org/why_black_lives_matter_is_vital_for_us_ all 
Chinn, P. W. U. (2007). Decolonizing methodologies and indigenous knowledge: The role of culture, place and personal experience in professional development. Journal of Research in Science Teaching, 44(9), 1247-1268.

Cochran-Smith, M., \& Lytle, S. L. (2009). Inquiry as stance: Practitioner research for the next generation. New York, NY: Teachers College Press.

Cohen, B. D., Tokunaga, T., Colvin, D. J., Mac, J., Martinez, J. S., Leets, C., \& Lee, D. H. (2013). When the social justice learning curve isn't as steep: How a social foundations course changed the conversation. Educational Studies, 49(3), 263-284.

Convertino, C. (2016). Beyond ethnic tidbits: Toward a critical and dialogical model in multicultural social justice teacher preparation. International Journal of Multicultural Education, 18(2), 125-142.

Fusion Comedy. (2016, October 5). How microaggressions are like mosquito bites - Same difference [Video file]. Retrieved from https://www.youtube.com/ watch? $\mathrm{v}=\mathrm{hDd} 3 \mathrm{bzA} 7450$

Gardner, H. (2011). Frames of mind: The theory of multiple intelligences. New York, NY: Basic Books. (Original work published in 1983).

Garza, A. (2014, October 7). A herstory of the \#BlackLivesMatter movement by Alicia Garza [Blog]. Retrieved from http://www.thefeministwire.com/2014/ 10/blacklivesmatter-2/

Gay, G., \& Howard, T. C. (2000). Multicultural teacher education for the $21^{\text {st }}$ century. The Teacher Educator, 36(1), 1-16.

Gorski, P. C. (2009). What we're teaching teachers: An analysis of multicultural teacher education coursework syllabi. Teaching and Teacher Education, 25(2), 309-318.

Gorski, P. C. (2012). Instructional, institutional, and sociopolitical challenges of teaching multicultural teacher education courses. The Teacher Educator, 47(3), 216-235.

Gorski, P. C., Davis, S. N., \& Reiter, A. (2012). Self-efficacy and multicultural teacher education in the United States: The factors that influence who feels qualified to be a multicultural teacher educator. Multicultural Perspectives, 14(4), 220-228.

Guiding principles | Black Lives Matter. (n.d.). Retrieved from http://blacklivesmatter.com/guiding-principles/

Gutiérrez, R. (2000). Is the multiculturalization of mathematics doing us more harm than good? In R. Mahalingam \& C. McCarthy (Eds.), Multicultural curriculum: New directions for social theory, practice and policy (pp. 199219). New York, NY: Routledge.

Herrera, S. G., Holmes, M. A., \& Kavimandan, S. K. (2012). Bringing theory to life: Strategies that make culturally responsive pedagogy a reality in diverse 
secondary classrooms. International Journal of Multicultural Education, 14(3), 1-19.

Hirasawa, Y. (2009). Multicultural education in Japan. In J. A. Banks (Ed.), The Routledge international companion to multicultural education (pp. 159-169). New York, NY: Routledge.

hooks, b. (1994). Teaching to transgress: Education as the practice of freedom. New York, NY: Routledge.

Howard, T. C. (2003). Culturally relevant pedagogy: Ingredients for critical teacher reflection. Theory into Practice, 42(3), 195-202.

Howard, T. C. (2010). Why race and culture matter in schools: Closing the achievement gap in America's classrooms. New York, NY: Teachers College Press.

Hubbard, R. S., \& Powers, B. M. (2003). The art of classroom inquiry: A handbook for teacher-researchers. Portsmouth, NH: Heinemann.

Jackson, L. (2013). Multicultural or intercultural education in Hong Kong? International Journal of Comparative Education and Development, 15(2), 99-111.

Jenks, C., Lee, J. O., \& Kanpol, B. (2001). Approaches to multicultural education in preservice teacher education: Philosophical frameworks and models for teaching. The Urban Review, 33(2), 87-105.

Kasun, G. S. (2015). Teacher education Nepantlera work: Connecting cracksbetween-worlds with Mormon university students. International Journal of Multicultural Education, 17(3), 91-106.

Kedley, K. E. (2015). Queering the teacher as a text in the English Language Arts classroom: Beyond books, identity work and teacher preparation. Sex Education, 15(4), 364-377.

Kemmis, S. (2006). Participatory action research and the public sphere. Educational Action Research, 14(4), 459-476.

Kozol, J. (2005). Still separate, still unequal: America's educational apartheid. Harper's Magazine, 9, 41-54.

Kushner, J. (2016, March 22). The voluntourist's dilemma. The New York Times Magazine. Retrieved from https://www.nytimes.com/2016/03/22/magazine/ the-voluntourists-dilemma.html

Ladson-Billings, G. (2011). "Yes, but how do we do it?": Practicing culturally relevant pedagogy." In J. G. Landsman \& C. W. Lewis (Eds.), White teachers / diverse classrooms: Creating inclusive schools, building on students' diversity, and providing true educational equity (pp. 33-46). Sterling, VA: Stylus Publishing.

Leitch, R., \& Day, C. (2000). Action research and reflective practice: Towards a holistic view. Educational Action Research, 8(1), 179-193. 
Livingston, K., \& Flores, M. A. (2017). Trends in teacher education: A review of papers published in the European Journal of Teacher Education over 40 years. European Journal of Teacher Education, 40(5), 551-560.

Lopez, A. E. (2011). Culturally relevant pedagogy and critical literacy in diverse English classrooms: A case study of a secondary English teacher's activism and agency. English Teaching: Practice and Critique, 10(4), 75-93.

Lorde, A. (1984/2007). Sister outsider: Essays and speeches. Berkeley, CA: Crossing Press.

Milner, H. R. (2011). But good intentions are not enough: Doing what's necessary to teach for diversity. In J. G. Landsman \& C. W. Lewis (Eds.), White teachers / diverse classrooms: Creating inclusive schools, building on students' diversity, and providing true educational equity (pp. 56-74). Sterling, VA: Stylus Publishing.

Muchenje, F. (2017). Cognitive justice and indigenous knowledge systems in the postcolonial classroom. In E. Shizha \& N. Makuvaza (Eds.), Re-thinking postcolonial education in Sub-Saharan Africa in the 21st century: PostMillennium development goals (pp. 69-83). Rotterdam, The Netherlands: SensePublishers. Retrieved from https://link.springer.com/content/pdf/ 10.1007\%2F978-94-6300-962-1.pdf

Muchenje, F., \& Heeralal, P. J. H. (2014). Teachers' perceptions of the implementation of multicultural education in primary schools in Chegutu District, Zimbabwe. Journal of Social Sciences, 41(3), 325-333. Retrieved fromhttps://www.researchgate.net/profile/Prem_Jotham_Heeralal_Heerala I/publication/302406399_Teachers\%27_Perceptions_of_the_Implementati on_of_Multicultural_Education_in_Primary_Schools_in_Chegutu_District_ Zimbabwe/links/573056d708aeb1c73d14545f/Teachers-Perceptions-ofthe-Implementation-of-Multicultural-Education-in-Primary-Schools-inChegutu-District-Zimbabwe.pdf

Nieto, S. (2003). Profoundly multicultural questions. Educational Leadership, 60(4), 6-10.

Nieto, S., \& Bode, P. (2012). Affirming diversity: The sociopolitical context of multicultural education (6th ed.). Boston, MA: Pearson.

Palmer, P. J. (1998). The courage to teach. San Francisco, CA: Jossey-Bass.

Paul-Binyamin, I., \& Reingold, R. (2014). Multiculturalism in teacher education institutes-The relationship between formulated official policies and grassroots initiatives. Teaching and Teacher Education, 42, 47-57.

Salazar, M. C., \& Rios, F. (2016). Just scholarship! Publishing academic research with a social justice focus. Multicultural Perspectives, 18(1), 3-11.

Schön, D. A. (1987). Educating the reflective practitioner: Toward a new design for teaching and learning in the professions. San Francisco, CA: Jossey Bass. 
Shannon-Baker, P., \& Talbot, S. (2016). Even the dirt is dangerous: Racism in U.S. American study abroad programs. In V. Stead (Ed.), RIP Jim Crow: Fighting racism through higher education policy, curriculum, and cultural interventions (pp. 405-416). New York, NY: Peter Lang Publishing.

Shannon-Baker, P., \& Wagner, I. (in press). Battling heteronormativity in teacher education: Reflections on a human development course from a teacher and student. In A. D. Martin \& K. J. Strom (Eds.), Disruptive views of gender and sexuality in k-12 and teacher education. Charlotte, NC: Information Age Publishing.

Sheets, R. H., \& Chew, L. (2002). Absent from the research, present in our classrooms: Preparing culturally responsive Chinese American teachers. Journal of Teacher Education, 53(2), 127-141.

Simpson, L. (2014, December 5). An indigenous view on \#BlackLivesMatter. Yes! Magazine. Retrieved from http://www.yesmagazine.org/peace-justice/ indigenous-view-black-lives-matter-leanne-simpson

Sleeter, C. E. (1996). Multicultural education as a social movement. Theory into Practice, 35(4), 239-247.

Smith, C. (2014). Culturally relevant pedagogy in multicultural teacher education: A paradoxical objective (Unpublished doctoral dissertation). University of Minnesota, Twin Cities, Minneapolis, MN. Retrieved from http://conservancy.umn.edu/bitstream/handle/11299/167577/Smith_umn_ 0130E_15240.pdf?sequence $=1$ \&isAllowed $=\mathrm{y}$

Solórzano, D. G. (1998). Critical race theory, race and gender microaggressions, and the experience of Chicana and Chicano scholars. International Journal of Qualitative Studies in Education, 11(1), 121-136.

Stenhouse, V. L. (2012). Teacher educators' understanding of diversity: Painting a picture through narrative portraits. Multicultural Education, 19(4), 14-23.

Sue, D. W., Capodilupo, C. M., Torino, G. C., Bucceri, J. M., Holder, A. M. B., Nadal, K. L., \& Esquilin, M. (2007). Racial microaggressions in everyday life: Implications for clinical practice. American Psychologist, 62(4), 271286.

Tuck, E. (2013). Neoliberalism as nihilism? A commentary on educational accountability, teacher education, and school reform. Journal for Critical Education Policy Studies, 11(2), 324-347.

Tuck, E., \& Yang, K. W. (2012). Decolonization is not a metaphor. Decolonization: Indigeneity, Education \& Society, 1(1), 1-40.

Valencia, R. R. (2010). Dismantling contemporary deficit thinking: Educational thought and practice. New York, NY: Routledge.

Wallace, D. M. (2016). Liberation through education: Teaching \#BlackLivesMatter in Africana Studies. Radical Teacher, 106, 29-39. 
Welling-Cann, J., \& Stoll, E. (2016). Good white people [Video file]. Retrieved from https://www.youtube.com/watch?v=xdUsZaJ80zl

Zakaria, R. (2014, April 21). The white tourist's burden. Al Jazeera America [Oped]. Retrieved from http://america.aljazeera.com/opinions/2014/4/voluntertourismwhitevoluntouristsafricaaidsorphans.html

Zeichner, K. M., \& Gore, J. M. (1995). Using action research as a vehicle for student reflection. In S. Noffke \& R. B. Stevenson (Eds.), Educational action research: Becoming practically critical (pp. 13-30). New York, NY: Teachers College Press.

\section{Author Contact}

Peggy Shannon-Baker: pshannonbaker@georgiasouthern.edu

Georgia Southern University, 1332 Southern Dr., Statesboro GA, 30458 